\title{
Muslim Religiosity, Generational Cohorts and Buying Behaviour of Islamic Financial Products
}

\begin{abstract}
:
This study examines the effects of the interplay between various aspects of religiosity, generational cohorts, and buying attitude on Muslim Consumers' purchase intention of Islamic financial products. Based on data collected from 1263 Muslim consumers in Bangladesh, the findings broadly support the proposed conceptual model that buying attitude acts as a mechanism that transforms religiosity dimensions of Muslims into purchase intention, and that the Muslim religiosity - buying attitude - purchase intention relationship is moderated by generational cohorts. The unbundling of the religiosity construct provides a deeper understanding of how the mediating (buying attitude) and moderating (generational cohorts) relationships vary across various religiosity dimensions.
\end{abstract}

Keywords: Buying behaviour, Religion, Religiosity of Muslims, Islamic finance, Generational cohorts.

\section{Please cite this paper as}

Sharma, R. R., Newaz, F. T., \& Fam, K. S. (2017). Muslim religiosity, generational cohorts and buying behaviour of islamic financial products. Australian Journal of Management, 42(3), 482-501. doi:doi:10.1177/0312896216659530 


\section{Introduction}

While considerable research identifies the effects that religion can have on international marketing decisions, the concept of religiosity in the context of Islam remains limited (Shukor and Jamal, 2013). Most of the current research on religiosity focuses on Christianity in the context of the Western world (Gait and Worthington, 2008). However, studies about Islamic religious influences on business practices are gaining momentum (Muhamad and Mizerski, 2013). Religiosity is an individual's level of commitment to a particular religious group, while religion or religious affiliation is the denominational membership or religious identification of an individual (e.g. Christian, Muslim, Hindu, or Buddhist) (Delener, 1990; McDaniel and Burnett, 1990). It is not consumers' affiliation to a religion, but rather the extent to which they follow the teachings and conduct of the religion (i.e. religiosity) that is likely to influence their behaviour (Hirschman, 1981). There is a clear differentiation between degrees of religiosity among Muslims: some Muslims are seen as pious and others are not (Youssef et al., 2011).

Islam has two main branches: Sunni and Shiite. The differences between the two branches lie mostly in the interpretation of the Hadiths and of Sharia law (Rizvi, 2014). The hadiths are the collected reports of what the Prophet Muhammad said and did during his lifetime. These collected reports are an important source of Islamic guidance, and are often referred to in matters of Islamic law by most Muslims. Sunnis view the hadiths as the second source of revealed law, complementary to the Noble Quran. Therefore, it is not permissible to contradict or reject the rulings and directives contained in those hadiths. Shiites are unlikely to rely heavily on the practice of the Prophet and his teachings. In Arabic, Sharia means 'path'. Derived from the Quran and hadiths, sharia guides all aspects of Muslim life, including religious obligations (Johnson and Sergie, 2014). Sharia divides all actions into forbidden (haram) and permitted (halal). Between the two sects, the Shiites consider their 
Imams to be infallible, and to have the right to create new rulings and directives in contradiction to the revealed law. The Sunnis adhere strictly to the legal rulings and directives of the Quran and believe that no one has the right to formulate new legislation or directives (Council on Foreign Relations). However, both sects follow the five ritualistic pillars of Islam, share the Quran and regard the Prophet Muhammed as being the last messenger of God. As this study focuses on buying behaviour of Islamic financial products in the light of Muslims' overall religiosity, it does not distinguish between Sunnis and Shiites but considers Muslim religiosity in general and how it impacts Muslim consumers' buying behaviour towards Islamic Financial Products (IFPs).

Religion is highly personal in nature and thus its influences on consumer behaviour depend on a person's degree of religiosity (Swimberghe et al., 2009). Islam guides Muslims in every aspect of life, not just in particular acts of worship but also in how and what to trade, how to interact with others and what can be consumed (Alam et al.,; Razzaque and Chaudhry, 2013). Islamic laws govern and rule financial services (Marinov, 2007). Iqbal (1997) notes the overall guiding principles of Islamic finance such as avoiding speculation, making money from money, predetermined payment over and above the amount lent, investing in practices or products not supported by Islam, and sharing profits and losses arising from projects for which money was lent. Money is viewed as a medium of exchange, and therefore should not be allowed to give rise to more money, via fixed interest payments, simply by being put in a bank, or by being lent to someone else. Religious Muslims tend to focus on 'halal' (permissible) products and avoid 'haram' (forbidden) products. Thus, the guiding principles of Islamic finance are likely to influence religious Muslims' decision making process (Razzaque and Chaudhary, 2013; Yousaf and Malik, 2013) with respect to IFPs.

The Islamic finance industry has evolved from a 'fringe industry' in the 1960s that provided for the specific banking requirements of the Muslim community, to a global industry 
incorporating banking, insurance and capital markets for both Muslim and non-Muslim consumers (IFSB, IDB, and IRTI, 2010). The Islamic finance industry is experiencing rapid growth, having grown threefold during the past five years. The global assets of the Islamic financial services industry increased from USD 531 billion in 2006 to USD 1.6 trillion at the end of 2012 (Grewal, 2013). This trend has encouraged conventional financial institutions from developed economies to become involve in the Islamic financial market.

Given the significance of the IFP industry and the limited amount of research on Muslim religiosity and buying behaviour, we aim to examine 1) the religiosity and buying behaviour relationships of Muslims for IFPs, and 2) how such relationships vary across generational cohorts. We contribute to the existing religiosity buying behaviour research in five ways. First, we unbundle the construct of religiosity to its various dimensions and link it to the purchase intention of IFPs. Second, we provide an understanding of how each religiosity dimension influences purchase intention directly and indirectly through buying attitude. Third, we demonstrate how 'religiosity - buying behaviour' relationships vary across generational cohorts. Next, we compare the moderating effects of actual and perceived generational cohorts which endorse and extend the applicapbility of generational cohort theory to Muslim consumers. Lastly, we provide some useful guidelines for international marketers to leverage the potential in the Islamic financial industry.

\section{Theory and Conceptual Development}

\subsection{Religiosity, buying attitude and purchase intention}

The influence of religiosity on buying behaviour varies across countries, even those with the same religion. For example, Sood and Nasu (1995), and Siguaw et al. (1995) found the impact of Christian religiosity to be stronger for American consumers, less strong for New Zealand consumers and non-significant for Japanese consumers. Similarly, some evidence suggests 
that religion does not necessarily predispose a customer to select an Islamic bank (Gait, 2009). A study of Jordanian customers found that factors such as fast and efficient services, the bank's reputation and image, and the confidentiality of the bank were considered to be more important than religiosity (Erol and El-Bdour, 1989). However, most of the literature on Muslim religiosity and buying behaviour suggests that in Muslim-majority countries like Kuwait, Saudi Arabia and Egypt, religious factors are the main reason for choosing Islamic banks (Hegazy, 1995). Similar results have been found for Islamic bank customers in Bahrain (Metawa and Almossawi, 1998), Malaysia (Zainuddin et al., 2004; Alam et al., 2012), Indonesia (Dahari et al., 2015) and Turkey (Okumus, 2005) where Muslim consumers expressed religion as their primary motivation for the use of Islamic banking. Religiosity has been found to be the main influencing factor for Muslims when purchasing Islamic financial products (Omer, 1992), selecting an Islamic bank (Khan et al., 2007; Metawa and Almossawi, 1998), and procuring Islamic home financing (Alam et al., 2012). These studies indicate that Islamic banks enjoy a relatively strong power base among those customers who emphasize adherence to Islamic principles in the practices of the financial institutions they select.

The intention to purchase is the main determining factor of actual buying behaviour (Morwitz et al., 2007). The positive relationship between religiosity and purchase intention is widely accepted (Lindridge, 2005; Mokhlis, 2009, Al-Hyari et al., 2012). However, the impact of religiosity on the buying behaviour of Muslim consumers is more profound (Ismail et al., 2012) as Islamic society is affected by a distinct Islamic worldview based on Sharia. Islamic tenets are very clear about what a practicing Muslim is and isn't permitted to consume. The more pious a Muslim consumer is, the more likely the consumer will exercise caution in purchasing the product. Highly religious Muslims tend to view even low involvement goods like food products and personal hygiene products as high involvement 
since they want to ascertain whether these products conform to Sharia guidelines (Razzaque and Chaudhry, 2013).

Specifically, these Muslim consumers will consider buying a product if they are assured that that product does not violate or contradict their sacred beliefs. Muslim religiosity impacts Muslim consumers' purchase involvement (Rehman and Shabbir, 2010) and intention to choose Sharia compliant products (Mukhtar and Butt, 2012). With Islamic financial institutions offering Islamic financial products and services that adhere to Islamic principles, values and goals; we predict that religious reasons are the principle motivator for Muslims in dealing with Islamic financial institutions (Amin et al., 2011; Omer, 1992). Despite the fact the all Muslims are supposed to live both their material and spiritual life as per Sharia guidelines, it is naïve to claim that all Muslims have the same level of religious commitment (Fam et al., 2004). Pious Muslims are likely to be more dogmatic and conservative than less religious individuals (Delener, 1994). The choice of halal products is influenced by a Muslim consumers' level of religiosity, as highly religious Muslims are likely to live their lives according to Islamic rules.

H1: The greater the degree of religiosity of a Muslim, the greater the intention to purchase Islamic financial products.

In addition to directly influencing purchase intention, religiosity is likely to influence it indirectly through buying attitude. Attitude can be defined as an "overall evaluation that expresses how much people like or dislike an object, issue, person or action" (Hoyer et al., 2013 p.128). Religiosity influences a consumer's attitude, which is then reflected in that consumer's behaviour. People with strongly religious characteristics are considered to have a high level of religious commitment, upon which they base their attitudes towards the attributes of products (Budiman, 2012; Razzaque and Chaudhry, 2013). 
Religion and religiosity are found to influence attitudes towards the advertising of different products and services (Fam et al., 2004; Fam and Waller, 2004). Religiosity influences behaviours such as advertising message perception, consumption patterns, innovativeness, media usage, family decision making, purchase risk aversion and retail patronage behaviour (Mokhlis, 2006). For example, there is a negative relationship between religiosity and consumers' attitudes and the recall scores of TV advertisements perceived to include contentious elements. In one study, Christian and Muslim people with higher levels of religious commitment had significantly less positive attitudes towards the contentious messages, while conservative Muslims had much lower recall scores than liberal Muslims (Michell and Al-Mossawi, 1999). Sun et al. (2012) explored the effects that religious affiliation and commitment have on the intention of young adults in Southeast Asia to adopt Islamic mobile phone banking. The study found differences between pious and casually religious Muslims in their choice of Islamic mobile phone banking service. Devout Muslims were symbolic-oriented with their evaluation criteria, whereas casually-religious Muslims relied upon the utilitarian attributes of the banking service.

Although Islam mandates strict laws in terms of buying financial products and services, the extent to which its adherents follow those Sharia laws is likely to vary (Youssef et al., 2011) and this variation is affected by attitude (Ajzen, 1991). The extent to which Muslims will have a buying attitude towards IFPs depends on the degree to which an individual is religious (Soesilowati, 2010). Overall, religiosity impacts devotees' beliefs and attitudes toward a particular element through its doctrines. A consumer's intention to purchase a product or service is predicated on a positive attitude towards that particular product or service. Because religion influences attitudes and purchasing decisions, the Islamic financial industry expects Muslims to view Islamic finance as relevant to the Muslim obligation (Essoo and Dibb, 2004; Loo, 2010). A number of studies in the areas of marketing, 
banking and finance have shown the significant effect of attitude on intention (Shih and Fang, 2006; Zainuddin et al., 2004; Amin et al., 2011; Taib et al., 2008; Razzaque and Chaudhry, 2013) with the argument that a behavioural intention reflects a person's decision to perform the behaviour (Ajzen, 1991).

The theory of reasoned action (TRA) suggests that buying attitude acts as a mechanism that transforms Muslim religiosity into purchase intention. In other words, religiosity influences attitude and thus intention to purchase IFPs. According to TRA, consumers consider the significance of alternative behaviours before engaging in them and they decide to perform behaviours that they associate with desired outcomes (Fishbein and Ajzen, 1975; Gait, 2009; Razzaque and Chaudhry, 2013). The theory suggests that "an individual's intention to perform a specific behaviour is a linear function of his or her affective response to performing the behaviour (attitude) and perceived social norms about the behaviour" (Baker et al., 1996; p.531). Further, the theory of planned behaviour, an extension of TRA, considers perceived behavioural control and links attitude to behaviour (Ajzen, 1991). In the light of these theories and in line with the literature discussed above, we argue that the impact of Muslim religiosity on purchase intention occurs through buying attitude.

H2: Muslim consumers' buying attitude mediates the association between religiosity of a Muslim and purchase intention of IFPs.

H2a. The greater the degree of religiosity of a Muslim, the greater the Muslim individual's favourable attitude towards IFPs.

H2b: Muslim consumers with a more favourable attitude towards IFPs have a higher purchase intention of IFPs. 


\subsection{The moderating role of generational cohorts}

As per the generational cohort theory (GCT), individuals in the same generation tend to think and act differently from those born in other time periods (Inglehart, 1997; Rogler, 2002). On the premise of GCT, we argue that the relationships between religiosity, buying attitude, and purchase intention are likely to vary across different generational cohorts. A generational cohort can be defined as a group of people who were born during the same time and share similar external events during their late adolescence and early adulthood (Mannheim, 1952; Ryder, 1965). These external events are defining moments of their lives. As these societal events have primacy, they define generational cohorts and give rise to new cohorts (Noble and Schewe, 2003). The external events create homogeneity in a generational cohort by influencing generational cohort preferences, desires, attitudes, and buying behaviour and these elements remain present for the entire lives of the members of the cohort (Meredith et al., 2002). Generational cohorts are influenced by macro-level socialisation (e.g. external social, historical, political events) (Mannheim, 1952) and micro-level socialisation (e.g. family, peers, religion, media and ethnic groups) (Noble and Schewe, 2003). Generational cohort is a sociological theory and does not claim to be able to explain individuals' actions or to predict individuals' behaviour. But combined with personality profiles, including religion, it can be a very useful additional step for the analysis of behavioural drivers (Codrington, 2011). Thus, it can be argued that focusing on religiosity (micro-level socialisation) and generational cohorts (macro-level socialisation) is likely to provide a deeper understanding of the buying behaviour of individuals.

The purchase behaviour of different generational cohorts is found to vary according to their product preferences (Dann, 2007) for beverages (Rentz et al., 1983), motion pictures (Holbrook and Schindler, 1989), automobiles (Braun-LaTour et al., 2007), formal and informal attire (Arsenault and Patrick, 2008), and travel (Lehto et al., 2008). Rodriguez 
(1993) found that the purchasing power of middle and lower socioeconomic cohorts of Peruvians was influenced by their degree of religiosity. In a study of the attitudes of three different Chinese generational cohorts towards the advertising of controversial products, Fam et al. (2008) found that the Red Generation was extremely offended by the advertising of gender/sex related products (bras, condoms, underwear) as they were likely to be uneducated and to adhere to traditional values. In contrast, the Cultural Revolution cohort and Gen Y cohort perceived the advertising of gender/sex related products inoffensive. The authors conjectured that these two cohorts were the product of Chairman Mao's reconstruction of gender, where women were able to voice their own opinions and challenge male authority within the family.

However, the extent to which generational cohorts' purchase behaviour varies among Muslim consumers of Islamic financial products has not been examined. Given that Muslims are expected to live their material and spiritual life according to Islamic norms, it is of interest to discover whether the extent of religiosity of different cohorts has a varied impact on their purchase behaviour. It is likely to help international marketers to design marketing strategies specifically for the large and growing IFP market. The religiosity of different generational cohorts and their consumption-related attitude may also differ and religious consumers can be identified as clusters (Loroz, 2006). The older and middle generations are more religious than the younger generation, though a large number of people in all generations claim to be religious (Markides and Cole, 1984). A secularisation hypothesis argues that economic growth, industrialisation, increased literacy and decreasing fertility reduce religiosity (Akdede and Hotunluoğlu, 2008). Thus, based on the secularisation theory and characteristics of each generational cohort, the Traditionalists are more conservative than the other two cohorts: GenY and the Swing Generation (Mitchell, 2003). They emphasise traditional and religious ethics, and place importance on loyalty and commitment (Billings and Kowalski, 2004). 
Compared to GenY, Swing individuals consider themselves to be conservative but GenY is more open to change than the other two cohorts (Mitchell, 2003). This implies that there are differences in personal values and attitudes between the members of the three generations. Thus:

H3: Generation cohort moderates the relationships between religiosity of a Muslim and purchase intention of IFPs.

H3a: Traditionalists will exhibit a stronger positive relationship between customers' religiosity, buying attitude, and purchase intention of IFPs than the Swing cohort.

H3b: The Swing cohort will exhibit a stronger positive relationship between a customers' religiosity, buying attitude and purchase intention of IFPs than GenY.

* Figure 1-Conceptual Model - about here*

Based on the discussion above, a conceptual model is presented in Figure 1. The model shows the mediating effects of buying attitude in the relationship between religiosity and purchase intention. Further, the model posits a moderating effect of generational cohorts on the relationship between religiosity, buying attitude, and purchase intention. Previous research has suggested that consumers' attitude and selection of financial services and products might depend on demographic factors such as age, gender, household income, and educational attainment (Boyd et al., 1994; Devlin, 2002). Accordingly, the model uses a range of control variables which may influence these relationships and thus need to be controlled for to seek the actual effects of the main variables of interest. 


\section{Methodology}

\subsection{Research setting}

The context for testing the proposed hypotheses is the IFPs industry in Bangladesh. Bangladesh is one of the largest Asian Muslim countries in the world, with about 150 million Muslims providing a potential client base for IFPs. Although the Islamic banking market in Bangladesh started with a very limited resource base, it has shown strong growth throughout the past two decades. Currently Bangladesh is ranked $11^{\text {th }}$ among the top 15 countries in terms of Sharia-compliant assets, with a $1 \%$ market share of the global Islamic finance industry (OIC, 2012). This growing market shares means that Bangladesh is fast becoming a focal market. Its ongoing development signals a high level of acceptance by the public in general. Coupled with the country's economic growth, the market share of Islamic financial institutions continues its increase in terms of assets, financing and deposits (NewHorizon, 2009; Masry et al., 2015). Bangladesh is one of the potential markets for IFPs. It has a population three times that of the Gulf Cooperative Council (GCC) region which accounts for $40 \%$ of the global market share of IFPs. Bangladesh also has a growing urban middle class, a dynamic microfinance sector, and strong support from regulators (Ethica, 2012). Out of 47 banks in Bangladesh, seven private commercial banks are operating as fully-fledged Islamic banks. An additional 16 conventional banks are engaged in Islamic banking. Moreover the democratic nature of the country provides an interesting context to analyse the influence of religiosity on buying behaviour as there is no enforcement to buy Islamic financial products but consumers are nonetheless likely to buy such products of their own volition.

\subsection{Data}

The data for this research is collected from five major cities in Bangladesh using the 'pencil and paper' questionnaire survey method. The five cities represent different geographical 
regions of the country: Dhaka (Centre), Chittagong (South-East), Rajshahi (North), Khulna (South-West) and Sylhet (North-East). As all banking services are concentrated in urban areas, the choice of metropolitan cities to represent the country's banking sector is justified. The target participants were 18 years of age and over, male and female, and Muslim. In order to represent all the generational cohorts, a stratified sampling method was used whereby the target respondents were recruited from leading public universities (BBA and MBA students), business organisations (government and private) and associations of retired employees in all of the five cities. Both personal contacts and social networks were used to obtain the respondents from the above targeted organisations. One of the authors distributed a total of 1,800 questionnaires personally. Out of these, 1,263 questionnaires were found complete and usable, leading to a $70 \%$ response rate. The achieved response rate is higher than the benchmark average aggregate response rate of about 50\% at individual level (Baruch and Holtom, 2008). Table 1 shows that the sample is diverse and representative in terms of marital status, employment, location, monthly income and generational cohorts. The sample is not representative in terms of gender, with $86 \%$ of respondents being male. However, considering the male-dominated society, this skewness towards males is not surprising.

* Table 1- sample characteristics - about here *

\subsection{Measures}

The main variables of interest for this study are Muslim religiosity, buying attitudes, purchase intention and generational cohorts. Muslims' religiosity can be represented by Taqwa as a multidimensional concept based on Quran and Sunnah, and other Islamic studies (Ilyas, 1992). In this study, we have used the Taqwa dimensions as suggested by Salleh (2012) as various aspects of a Muslim's religiosity. The five dimensions of Taqwa are: belief (aqi'dah), practice ('amal), knowledge (ma'rifah), experience (ihsan) and consequence (natijah). The 
measures of the five dimensions align with the measures used by Stark and Glock (1968), Hassan (2007) and Salleh (2012). Questions regarding religious belief included the overall beliefs associated with the religion, such as beliefs about God, the Prophet, the Quran and Hadith. The practice ('amal) dimension included questions regarding actions prescribed by religion such as: prayer, fasting, Duas', reading the Quran, and giving Zakat. The knowledge (ma'rifah) dimension asked questions about an individual's basic knowledge about religion; offering Sajjda at saints' graves; earning through haram means; avoiding minor and major sin; and following Islamic junctions in all matters of life. The experience (ihsan) dimension describes the practicality of the religion and the six questions used to measure it included the feeling of doing something against faith; being tempted by the devil, being afraid of Allah; being punished by Allah for doing something wrong; seeing others following Islamic teaching; and the importance religion places on answering questions about the meaning of life. The consequence (natijah) dimension refers to the importance of religion itself, which was measured by asking questions about respect for others and allowing others their rights according to Islamic injunctions; the avoidance of activities which hurt others; helping those who need help; being honest and fair with others; and avoiding humiliating others.

We define buying attitude as the degree of favourableness or unfavourableness of an individual's feeling towards a psychological object (Ajzen and Fishbein, 2000). "Consumers' attitude is a function of their evaluation of product-specific attributes or features" (Kotler et al., 2004). Therefore, attitude towards IFPs is measured through people's evaluations, feelings and tendencies towards Islamic finance. The measurement scale is designed in such a way as to elicit the relevant attributes of Islamic finance that could determine peoples' perception of IFPs. The scale items are adopted from Gait (2009) and Amin et al. (2011). The questionnaire statements asked the respondents to rate the degree to which: Islamic finance operates in accordance with the principles of Islamic law and follows interest-free and profit-and-risk- 
sharing principles; speculation is prohibited in Islamic finance; capital has a social and ethical purpose beyond pure and unfettered return; Islamic finance is in harmony with religious values.

A behavioural intention reflects a person's decision to perform a behaviour. The purchase intention of IFPs is measured in terms of a person's plan to engage in some action within a specified period of time, and the probability that he or she will perform a buying behaviour. Five items were used to measure the purchase intention, and the measurements items were adapted from Amin et al. (2011). The respondents were asked to rate the statements, which involved their eagerness to learn more about how a products relates to Islamic Sharia; their interest in using Islamic financial products and services; their interest in using Islamic financial products and services in the future or someday; and whether they would recommend Islamic personal financing to others.

We measured generational cohorts in two ways: by perception and by age. In order to identify the traits of each generational cohort and to make generational value assessments, the respondents were asked to tick one of three statements that best described them (perceived generational cohorts). The statements as shown in Appendix 1 were a short summary of all the traits of a particular cohort (Inglehart, 1997). Historical events and coming of age year were primarily used to identify the generational cohorts (actual generational cohorts). Therefore, the traditionalist cohort is defined as individuals who were born between the years 1929-1953 (mature around the independence year 1971, age in 2011: 58 - 82 years). The swing cohort is defined as individuals who were born between the years 1954-1972 (mature around the post-independence to economic recovery period, age in 2011: 40 - 57 years). GenY is defined as individuals who were born between the years 1973-1993 (mature around the democratic governance phase, age in 2011: 18-39 years) (Schewe and Meredith, 2004; Mitchell, 2003; Sheahan, 2005) 


\subsection{Methods}

We analysed the data using partial least squares structural equation modelling (PLS-SEM). The use of PLS-SEM is justified because our observed variables are univariate normal but multivariate non-normal (Hair et al., 2014 p.15). Moreover, PLS-SEM provides greater statistical power, maximises explained variance and gives results similar to covariance-based SEM with large samples (Hair et al., 2014 p.23). Moreover, the aim of theory building, i.e. finding out the mechanisms that influence religiosity - buying behaviour relationships, also justifies the use of PLS-SEM (Tsafe and Rahman, 2013). The measurement and structural models are analysed using SmartPLS sofwtare (Ringle et al., 2014).

\section{Results}

We analysed the results using a two-step approach as suggested by Hair et al. (2014 p.96): step one assesses the measurement model and step two assesses the structural model. While assessing the structural model, we tested the mediation first and then undertook a multi-group analysis to examine the moderating effects of generational cohorts on religiosity - buying behaviour relationships.

\subsection{The measurement model}

Table 2 summarises the measurement model and includes the construct items, internal consistency (composite reliability), convergent validity (factor loadings and average variance extracted). The discriminant validity (Fornell-Larker Criterion analysis) is shown in Table 3. PLS-SEM uses composite reliability instead of Cronbach's alpha as a measure of internal consistency as the former is a more conservative measure of reliability (Hair et al., 2014 p.101). Unlike Cronbach's alpha $(\alpha)$, the composite reliability $(\mathrm{Pc})$ prioritises items as per their reliability and is not sensitive to the number of items in a scale. The Pc for all the 
constructs ranges between 80 to 90 which is within the acceptable range of 70-90 (Nunally and Bernstein, 1994).

\section{*Table 2 about here*}

Convergent validity is considered at the item and construct levels. The item level convergent validity (also known as indicator reliability) is satisfied if all the factor loadings are .70 or higher, while the construct level convergent validity requires an average variance extracted value (AVE) of .50 or more (Hair et al., 2014 p.107). Table 2 shows that the AVE ranges between .59 to .69 and that all the factor loadings except one item (loading $=.67$ ) are more than $.70-$ thus meeting the convergent validity criteria. This item was kept in the model as items with a lower indicator reliability (between .40 and .70) can be kept in the measurement model if it makes theoretical sense and its deletion does not increase measures above threshold (Hair et al., 2014 p.106).

In case the square root of the AVE value is more than its highest correlation with any other construct, then the construct is said to have discriminant validity as per the FornellLarcker criterion (Hair et al., 2014 p.105). The square root values of AVE are shown as bold figures on the diagonal in Table 3. It is clear that all bold values are greater than their highest correlation with all other constructs. Also the factor loadings are significantly greater than their cross loadings. Based on the validity benchmarks in Tables 2 and 3, it is clear that the measurement model satisfies the reliability and validity criteria.

*Table 3 about here*

\subsection{The structural model}

We analysed the structural models in two phases: mediation analysis to analyse religiosity buying behaviour relationships, and multi-group analysis of the mediation paths to examine whether the proposed relationships vary across generational cohorts. The structural models 
were evaluated based on 5 criteria as suggested by Hair et al. (2014 pp. 97,186). The criteria include 1) size and significance of path coefficients, 2) coefficient of determination $\left(\mathrm{R}^{2}\right), 3$ ) predictive relevance $\left.\left(\mathrm{Q}^{2}\right), 4\right) \mathrm{f}^{2}$ effect sizes, and 5) $\mathrm{q}^{2}$ effect sizes. These criteria for the overall mediation analysis are shown in Figure 1. The value of $\mathrm{R}^{2}$ is .21 for buying attitude and .42 for purchase intention, implying that all the religiosity dimensions explain the $21 \%$ variation in the buying attitude, and these dimensions and buying attitude along with the control variables explain the $42 \%$ variation in the purchase intention of IFPs. The Stone-Geisser's $\mathrm{Q}^{2}$ values of greater than zero show that the model has predictive relevance (Geisser, 1975; Stone, 1974). The $\mathrm{q}^{2}$ effect size values of .16 and .13 imply that model has medium predictive relevance. $\mathrm{f}^{2}$ and $\mathrm{q}^{2}$ effect sizes of $.02, .15$ and .35 represent small, medium and large predictive relevance respectively (Cohen, 1988). Based on $\mathrm{R}^{2}, \mathrm{Q}^{2}$ and $\mathrm{q}^{2}$ values, it can be argued that the model predicts the proposed relationships well.

The path coefficients as shown in Figure 1 show that the buying attitude has a highly significant positive relationship with purchase intention with medium effect size. Religious practice, knowledge and experience of Muslims influence their purchase intention of IFPs directly, as well as indirectly through buying attitude. This indicates partial mediation which is also evident from the variance accounted for (VAF) value in Table 4. VAF values between .20 and .80 indicate partial mediation (Hair et al., 2014 p.220). The strength of the direct relationship between these three religious dimensions and purchase intention reduced after including the mediator. This is evident from the 'no mediator' column and 'direct effect' column in Table 4. The coefficient estimates and significance values of the indirect effects of these paths are highly significant as shown in Table 4. Therefore, the mediating effects of buying attitude in the association of religious practice, knowledge, and experience, and purchase intention of IFPs are highly significant and partial. However, their effect sizes are low. We find that the religious consequences dimension has a significant direct effect on 
Muslims' purchase intention of IFPs. The dotted lines in Figure 1 show non-significant relationships while solid lines represent significant relationships.

To examine whether generational cohorts moderate the religiosity - buying behaviour relationships, we undertook a multi-group analysis (MGA) (Hair et al., 2014 p.247; Ringle et al., 2014). While undertaking the MGA, we compared all the factor loadings, and reliability and validity criteria for all the factors across generational cohorts. Though some items show significant differences across generational cohorts, overall all the reliability and validity criteria were met across generational cohorts for all the constructs. The findings are summarised in Tables 5 and 6.

\section{* Tables 5 and 6 about here*}

Table 5 shows the moderation effects of perceived generational cohorts. The mediation findings across generational cohorts are similar for religious practice and knowledge but vary for religious consequences. Both religious practice and knowledge show significant partial mediation effects for all the generational cohorts as is shown by the overall mediation model. However, the religious experience dimension for GenY shows partial mediation, while it directly influences the purchase intention of the Swing Generation (GenS), and shows no influence on the buying behaviour of the Traditionalist Generation (GenT). The Welch Satterthwait test, a non-parametric test, for MGA of mediation paths reveals that there are significant differences in the direct effects of religious experience on buying attitude between GenY, GenS and GenT. GenY's religious experiences influence their buying attitude directly and their purchase intention indirectly. These relationships are direct for GenS and nonexistant for GenT. Other significant differences involve the religious practice of GenS and GenT. Relegious practice influences the purchase intention of GenS indirectly through buying attitude and in case of GenT, both directly and indirectly. 
For comparing actual age-based generational cohorts (Table 6) we combined GenS and GenT and compared it with GenY. This was done as the individual sample size of GenS and GenT was not large enough to run MGA. The moderating effects findings are similar to the perceived generational cohorts' comparison, with some exceptions. Among age-based generational cohorts, education and marital status significantly influences their purchase intention: as the level of education goes up, the purchase intention of GenS and GenT goes significantly down. This trend is reversed for GenY. Married GenS and GenT showed a higher purchase intention than single GenS and GenT consumers. The similar findings on mediation paths in actual generational cohorts and perceived generational cohorts endorse the generalizability of the perceived generational cohort comparisons where all the three cohorts are compared.

The moderating effects of generational cohorts suggest some similarities and differences: 1) The effects of the mediation paths for religious belief (non-significant) and practice (significant) are same across generational cohorts as in the overall model. 2) Religious knowledge shows both direct and indirect effects in the overall model, but its direct effects are not significant for GenY (perceptual cohorts) and GenS and GenTT (actual cohorts). 3) Similarly, religious experience has both direct and indirect effects in the overall model, but its direct and indirect effects vary across generational cohorts. 4) Finally, religious consequences that show direct effects in the overall model are significant for GenT only. The next question is whether these differences are statistically significant or not? Table 5 and 6 suggest that some of these differences are significant on some dimensions (experience, practice) for the perceived and actual generational cohorts. 


\section{Discussion and Conclusion}

For Muslims, everything an individual undertakes, including business practices and marketing, is part of the worship of Allah in Islam (Fam et al., 2004). Sharia law impacts on economic activities and has extensive implications for marketing in many Islamic countries. Exceptionally significant religious differences may incite serious disputes for non-Muslim multinationals operating in Islamic countries (Marinov, 2007). A number of countries with predominately Muslim populations have adopted Sharia law, which attempts to implement Islamic principles and ideals in everyday personal and business life. Considering the importance of religiosity in a Muslim's life, the potential market size of Islamic financial products and the relative lack of research in the field, we aimed to examine the influence of various aspects of Muslims' religiosity on their buying behaviour and the mechanisms that intervene in these relationships. The findings mainly support the proposed conceptual model: H1 (religiosity - purchase intention relationships) and H2 (mediation effects of buying attitude) are supported with varying degrees of strength across various religiosity dimensions; and $\mathrm{H} 3$ (moderation effects of generational cohorts) is supported with mixed evidence for $\mathrm{H} 3 \mathrm{a}$ and $\mathrm{H} 3 \mathrm{~b}$ (which cohort group has stronger influence on religiosity - purchase intention relationships across various religiosity dimensions).

We extend the Muslim religiosity - buying behaviour literature by combining insights from the theories of reasoned action and generational cohorts. In line with other Muslim religiosity studies, the tested model results broadly endorsed the basic tenet of the theory of reasoned action that purchase intention (intention to perform a behaviour) depends on attitude (affective response to perform the behaviour) (Ajzen, 1991, Baker et al., 1996; Fishbein and Ajzen, 1975; Razzaque and Chaudhry, 2013). Combining religiosity (micro-level socialisation) with generational cohorts (macro-level socialisation) has endorsed and extended the generational cohorts theory (Loroz, 2006; Mannheim, 1952; Noble and Schewe, 2003; 
Ryder, 1965) by establishing that consumer behaviour differs, but not always across generational cohorts. To the best of our knowledge, no other study has so far examined the interplay of both religiosity and generational cohorts on buying behaviour of Muslims.

By unbundling the religiosity construct into various dimensions we provide evidence as to the relative significance of religiosity dimensions in enhancing purchase intention and the mechanism that works in between: the mediating role of buying attitude and the moderating role of generational cohorts. The unbundling of religiosity dimensions and the related results suggest that religious practice, knowledge and experience enhance purchase intention directly as well as indirectly through buying attitude which signifies the importance of these dimensions in targeting segmented marketing programmes. The non-significant effects of religious belief suggest that they place their religious belief highly irrespective of their purchase intention. This finding is in contrast with recent findings by Razzaque and Chaudhary (2013) who found religious beliefs to have significant effects on consumer decision making. An explanation to our findings lies in the fact that Muslims are supposed to believe in Islam and they may find it socially undesirable to a lower valuing of religious belief. The unbundling of the religiosity construct into various dimensions in the light of Islamic religion explains the deeper insights as to what aspects of religiosity (rather than religiosity as a whole) influence buying behaviour and how. Even though multi-dimensional constructs are widely used and accepted as they provide greater parsimony and bandwidth, their use depends upon theoretical criteria (Johnson et al., 2011). As we aimed to find out differential effects of various religiosity dimensions, the use of standalone constructs is justified and provides deeper insights into the phenomenon.

The findings suggest which aspects of religiosity should be focussed on in marketing IFPs and which not. It is suggested to avoid marketing programmes that relate to the religious beliefs of Muslims for two reasons: One, we did not find any evidence that it enhances 
Muslims' purchase intention in any way; Two, Muslims are very sensitive to their belief which is evident from the publication of Prophet Muhammad cartoons and its negative ramifications for Western firms (Knight et al., 2009). Marketing programmes that leverage Muslim religious practice and knowledge are likely to influence Muslims' purchase intention for each generational cohort. GenY differs significantly from GenS and GenT in terms of the effect of religious experiences while the effect is strongest on GenY. This effect is significant for GenS and non-significant for GenT. It implies that marketing programmes leveraging this dimension will be more productive for GenY than for GenS, and non-productive for GenT. GenS and GenT also differ in terms of the impact of religious practice wherein this effect is stronger for GenT. Also significant are the effects of education and marital status in the comparisons among actual generational cohorts which indicate that marketing programmes need to focus on more educated GenY and relatively less educated GenS and GenT as these groups have been found to have higher purchase intention of IFPs than their counterparts. The findings also suggest that focusing on married GenS and GenT and single GenY is likely to be more productive. These religiosity - generational cohort based behaviour differences are also likely to guide organisations in managing Muslim employees and related decision making, though empirical investigation in the area is still required.

The findings need to be interpreted with some caution though. The outcome variable is the purchase intention but not the actual purchase of the products. The data is from one country and Muslims in other countries may display different buying behaviours. It would be useful to include the actual purchase decision in future studies with data from a set of Muslim countries representing the varying degree of religious freedom or enforcement. It would also be useful to compare the religiosity of consumers from different religions such as Muslims, Christians, Buddhists and Hindus. Moreover, buying behaviour may vary between Shiite and Sunni Muslims across various religiosity dimensions. Further, it would be interesting to see 
whether the influence of religiosity and spirituality differ on purchase behaviour. Also, the comparative impact of religiosity and spirituality on management practice is worth exploration to guide managerial decision making. 


\section{References}

Ajzen, I. (1991). The Theory of Planned Behavior. Organizational Behavior and Human Decision Processes, 50(2), 179-211.

Ajzen, I., and Fishbein, M. (2000). Attitudes and the attitude-behaviour relation: Reasoned and automatic processes. European Review of Social Psychology, 11, 1-33.

Akdede, S. H., and Hotunluoğlu, H. (2008). Economic Development and Religiosity: An Investigation of Turkish Cities. Paper presented at the International Conference on Emerging Economic Issues in a Globalizing World, Izmir.

Al-Hyari, K., Alnsour, M., Al-Weshah, G., and Haffar, M. (2012). Religious beliefs and consumer behaviour: from loyalty to boycotts. Journal of Islamic Marketing, 3(2), 155-174.

Alam, S. S., Janor, H., Zanariah, C. A. C. W., and Ahsan, M. N. (2012). Is religiosity an important factor in influencing the intention to undertake Islamic home financing in Klang Valley? World Applied Sciences Journal, 19(7), 1030-1041.

Alam, S. S., Mohd, R., and Hisham, B. (2011). Is religiosity an important determinant on Muslim consumer behaviour in Malaysia? Journal of Islamic Marketing, 2(1), 83-96.

Amin, H., Rahman, A. R. A., Sondoh, S. L., and Hwa, A. M. C. (2011). Determinants of customers' intention to use Islamic personal financing: The case of Malaysian Islamic banks. Journal of Islamic Accounting and Business Research, 2(1), 22-42.

Arsenault, P. M., and Patrick, M. L. (2008). Are the shoes appropriate to wear?: A study of cohort values. Journal of Targeting, Measurement and Analysis for Marketing, 16(2), 99-107.

Baker, S. A., Morrison, D. M., Carter, W. B., and Verdon, M. S. (1996). Using the Theory of Reasoned Action (TRA) to understand the decision to use condoms in an std clinic population. Health Education and Behavior, 23(4), 528-542.

Baruch, Y., and Holtom, B. C. (2008). Survey response rate levels and trends in organizational research. Human Relations, 61(8), 1139-1160.

Billings, D., and Kowalski, K. (2004). Teaching learners from varied generations. The Journal of Continuing Education in Nursing, 35(3), 104- 105.

Boyd, W., Leonard, M., and White, C. (1994). Customer preferences for financial services: An analysis. International Journal of Bank Marketing, 12(1), 9- 15.

Braun-LaTour, K. A., LaTour, M. S., and Zinkhan, G. M. (2007). Using childhood memories to gain insight into brand meaning. Journal of Marketing, 71(2), 45-60.

Budiman, S. (2012). Analysis of consumer attitudes to purchase intentions of counterfeiting bag product in Indonesia. International Journal of Management, Economics and Social Sciences, $1(1), 1-12$.

Codrington, G. (2011). Detailed introduction to generational theory in Asia. Tomorrow Today http://www.tomorrowtoday.uk.com/articles/pdf/TomorrowToday_Generations_in_Asia.pdf

Cohen, J. (1988). Statistical power analysis for the behavioral sciences (2nd ed.). Hillsdale, NJ: Erlbaum.

Council on Foreign Relations, "The Sunni-Shia Divide", http://www.cfr.org/peace-conflict-andhuman-rights/sunni-shia-divide/p33176\#!/

Dahari, Z., Abduh, A., and Fam, K.S., (2015). Measuring service quality in Islamic banking: Using importance and performance analysis approach. Asian Journal of Business Research, 5(2), in press

Dann, S. (2007). Branded generations: baby boomers moving into the seniors market. Journal of Product and Brand Management, 16(6), 429-431.

Delener, N. (1990). The effects of religious factors on perceived risk in durable goods purchase decisions. Journal of Consumer Marketing, 7(3), 27-38.

Delener, N. (1994). Religious contrasts in consumer decision behaviour patterns: Their dimensions and marketing implications. European Journal of Marketing, 28(5), 36.

Devlin, J. F. (2002). Customer knowledge and choice criteria in retail banking. Journal of Strategic Marketing, 10(4), 273- 290.

Erol, C., and El-Bdour, R. (1989). Attitudes, behaviour, and patronage factors of bank customers towards Islamic banks. International Journal of Bank Marketing, 7(6), 31-37. 
Essoo, N., and Dibb, S. (2004). Religious influences on shopping behaviour: An exploratory study. Journal of marketing management, 7(8), 683.

Ethica. (2012). Ethica Brings Global Islamic Finance Certification to Bangladesh. Dubai, UAE: Institute of Islamic Finance.

Fam, K.S., Waller, D. S., and Erdogan, B. Z. (2004). The influence of religion on attitudes towards the advertising of controversial products. European Journal of Marketing 38(5/6), 537-555.

Fam, K.S. and Waller, D.S. (2004). Ad likeability and brand recall in Asia: A cross-cultural study. Journal of Brand Management, 12(2), 93-104.

Fam, K.S., Waller, D.S., Ong, F.S. and Yang, Z. (2008). Controversial product advertising in China: Perceptions of three generational cohorts. Journal of Consumer Behaviour, 12 (1), 461-469.

Fishbein, M., and Ajzen, I. (1975). Belief, attitude, intention and behavior: An introduction to theory and research. Reading, MA: Addison-Wesley

Gait, A., and Worthington, A. (2008). An empirical survey of individual customers, business firm and financial institution attitudes towards Islamic methods of finance. International journal of Social Economics, 35(11), 783-808.

Gait, A. H. (2009). Libyan Attitudes towards Islamic Methods of Finance: An Empirical Analysis of Retail Consumers, Business Firms and Banks. Griffith University (Doctoral dissertation).

Geisser, S. (1975). The predictive sample reuse method with applications. Journal of the American Statistical Association, 70(350), 320-328.

Grewal, B. K. (2013). Overview of the Islamic Financial Landscape: Globally and in Europe. Kuwait Finance House Research Limited.

Hair, J. F., Hult, G. T. M., Ringle, C. M., and Sarstedt, M. (2014). A Primer on Partial Least Squares Structural Equations Modelling (PLS-SEM). California: SAGE Publications.

Hassan, R. (2007). On being religious: Patterns of religious commitment in Muslim societies. The Muslim World, 97(3), 437-478.

Hegazy, I. A. (1995). An empirical comparative study between Islamic and commercial banks' selection criteria in Egypt. International Journal of Commerce and Management, 5(3), 46-61.

Hirschman, E. C. (1981). American Jewish ethnicity: Its relationship to some selected aspects of consumer behavior. The Journal of Marketing, 45(3), 102-110.

Holbrook, M. B., and Schindler, R. M. (1989). Some exploratory findings on the development of musical tastes. Journal of Consumer Research, 16, 119-124.

Hoyer, W. D., MacInnis, D. J., and Pieters, R. (2013). Consumer Behavior (6th international ed.). Mason, Ohio: South-Western Cengage Learning.

IFSB, IDB, and IRTI. (2010). Islamic Finance and Global Financial Stability. Islamic Financial Services Board, Islamic Development Board, Islamic Research and Training Institute.

Ilyas, S. (1992). Dimensions of Muslim religiosity: Measurement considerations. Islamabad, Pakistan: International Institute of Islamic Thought.

Inglehart, R. (1997). Modernization and Postmodernization: Cultural, Economic, and Political Change in 43 Societies. Princeton, NJ: Princeton University Press.

Iqbal, Z. (1997). Islamic Financial System. Finance and Development, 34, 42-45.

Ismail, K., Vivishna, S., Khurram, W., and Jafri, S. K. A. (2012). Evaluating consumer purchase intentions for genetically modified food in Malaysia: A comparative study of Muslim and Non-Muslim consumers. Journal of Applied Sciences, Engineering and Technology, 4(5), 466-474.

Johnson, R., Rosen, C., and Chang, C.-H. 2011. To aggregate or not to aggregate: Steps for developing and validating higher-order multidimensional constructs. Journal of Business and Psychology, 26(3): 241-248.

Johnson, T. and Sergie, M.A., (2014). Islam: Governing Under Sharia, http://www.cfr.org/religion/islam-governing-under-sharia/p8034

Khan, M. S. N., Hassan, M. K., and Shahid, A. I. (2007). Banking behavior of Islamic bank customers in Bangladesh. Journal of Islamic Economics, Banking and Finance, 3(2), 159-194.

Knight, J. G., Mitchell, B. S., and Gao, H. (2009). Riding out the Muhammad cartoons crisis: Contrasting strategies and outcomes. Long Range Planning, 42(1), 6-22.

Kotler, P., Brown, L., Adam, S., and Armstrong, G. (2004). Marketing. NSW: Pearson Education Australia. 
Lehto, X. Y., Jang, S. S., Achana, F. T., and O'Leary, J. T. (2008). Exploring tourism experience sought: A cohort comparison of baby boomers and the silent generation. Journal of Vacation Marketing, 14(3), 237-252.

Lindridge, A. (2005). Religiosity and the construction of a cultural-consumption identity. Journal of Consumer Marketing, 22(3), 142-151.

Loo, M. (2010). Attitudes and perceptions towards Islamic banking among Muslims and Non-Muslims in Malaysia: Implications for marketing to Baby Boomers and X-Generation. International Journal of Arts and Sciences, 3(13), 453- 485.

Loroz, P. S. (2006). The generation gap: a Baby Boomer vs Gen Y comparison of religiosity, consumer values, and advertising appeal effectiveness. Advances in Consumer Research, 33(1), 308-309.

Lu, L., and Alon, I. (2004). Analysis of the changing trends in attitudes and values of the Chinese: The case of Shanghai's young and educated. Journal of International and Area Studies, 11(2), 6788 .

Mannheim, K. (1952). Essays on the Sociology of Knowledge. London: Routledge and Kegan Paul Ltd.

Marinov, M. (Ed.). (2007). Marketing in the Emerging markets of Islamic Countries: Palgrave Macmillan.

Markides, K. S., and Cole, T. (1984). Change and continuity in Mexican American religious behavior. Social Science Quarterly, 65, 618- 625.

Masry, A. A., Debes, A., and Baradie, M. E. (2015). Islamic and commercial banking systems: A theoretical comparison. Asian Journal of Business Research, 5 (1), 69-86.

McDaniel, S., and Burnett, J. (1990). Consumer religiosity and retail store evaluative criteria. Journal of the Academy of Marketing Science, 18(2), 101-112.

Meredith, G. E., Schewe, C. D., and Karlovich, J. (2002). Defining markets, defining moments: America's 7 generational cohorts, their shared experiences, and why businesses should care. New York, NY: John Wiley and Sons.

Metawa, S., and Almossawi, M. (1998). Banking behaviour of Islamic bank customers: Perspectives and implications. International Journal of Bank Marketing, 16(7), 299-315.

Michell, P., and Al-Mossawi, M. (1999). Religious commitment related to message contentiousness. International Journal of Advertising 18(4), 427-443.

Mitchell, S. (2003). American Generations: Who They Are. How They Live. What They Think (4th ed.). Ithaca, NY: New Strategist Publications.

Mokhlis, S. (2006). The effect of religiosity on shopping orientation: An exploratory study in Malaysia. Journal of American Academy of Business, Cambridge, 9(1), 64.

Mokhlis, S. (2009). Relevancy and measurement of religiosity in consumer behavior research. International Business Research, 2(3), 75-84.

Morwitz, V. G., Steckel, J. H., and Gupta, A. (2007). When do purchase intentions predict sales? International Journal of Forecasting, 23(3), 347-364.

Muhamad, N., and Mizerski, D. (2013). The effects of following Islam in decisions about taboo products. Psychology and Marketing, 30(4), 357-371.

Mukhtar, A., and Butt, M. M. (2012). Intention to choose Halal products: The role of religiosity. Journal of Islamic marketing, 3(2), 108-120.

NewHorizon. (2009). Global Perspective on Islamic Banking and Insurance. Institute of Islamic Banking and Insurance.

Noble, S. M., and Schewe, C. D. (2003). Cohort segmentation: an exploration of its validity. Journal of Business Research, 56(12), 979-987.

Nunally, J. C., and Bernstein, I. (1994). Psychometric Theory. New York: McGraw-Hill.

OIC. (2012). Islamic Finance in OIC Member Countries. Ankara, Turkey: Organization of Islamic Cooperation.

Okumuş, H. Ş. (2005). Interest-free banking in Turkey: A study of customer satisfaction and bank selection criteria. Journal of Economic Cooperation, 26(4), 51-86.

Omer, H. (1992). The Implication of Islamic Beliefs and Practice on Islamic Financial Institutions in the UK. Loughborough University (Doctoral dissertation). 
Rammal, H. G., and Zurbruegg, R. (2007). Awareness of Islamic banking products among Muslims: the case of Australia. Journal of Financial Services Marketing, 12(1),65-74.

Razzaque, M. A., and Chaudhry, S. N. 2013. Religiosity and Muslim consumers' decision-making process in a non-Muslim society. Journal of Islamic Marketing, 4(2): 198-217.

Rehman, A., and Shabbir, M. S. (2010). The relationship between religiosity and new product adoption. Journal of Islamic Marketing, 1(1), 6- 69.

Rentz, J. O., Reynolds, F. D., and Stout, R. G. (1983). Analyzing changing consumption patterns with cohort analysis. Journal of Marketing Research, 20, 12-20.

Ringle, C. M., Wende, S., and Becker, J.-M. (2014). Smartpls 3. http://www.smartpls.com. Hamburg.

Rizvi, K. (2014). Shia and Sunni Muslims - do you know the difference? http://www.yourmiddleeast.com/features/shia-and-sunni-muslims-do-you-know-thedifference_16339

Rodriguez, C.M. (1993). Relevancy, measurement and modeling of reliosity in consumer behaviour: The case of Peru. In G.S. Albaum and s.M. Smith (Eds.), Proceedings of the Fourth Symposium on Cross-Cultural Consumer and Business Studies, Kahuka, Hawaii.

Rogler, L. H. (2002). Historical generations and psychology: The case of the great depression and WWII. The American Psychologist, 57(12), 1013-1023.

Ryder, N. B. (1965). The cohort as a concept in the study of social change. American sociological review, 30, 843-861.

Salleh, M. S. (2012). Religiosity in development: A theoretical construct of an Islamic-based development. International Journal of Humanities and Social Science, 2(14), $266,274$.

Schewe, C. D., and Meredith, G. (2004). Segmenting global markets by generational cohorts: Determining motivations by age. Journal of Consumer Behaviour 4(1), 51- 63.

Sheahan, P. (2005). Generation Y: Thriving and surviving with Generation Y at work. Prahran, Victoria, Hardy Grant

Shih, Y. Y., and Fang, K. (2006). Effects of network quality attributes on customer adoption intentions of internet banking. Total Quality Management and Business Excellence, 17(1), 61-77.

Shukor, S. A., and Jamal, A. (2013). Developing Scales for Measuring Religiosity in the Context of Consumer Research. Middle-East Journal of Scientific Research, 13, 69-74.

Siguaw, J. A., Simpson, P. M., and Joseph, M. (1995). Religiosity effects on shopping behaviors: A comparative study of the U.S. and New Zealand. Paper presented at the Proceedings, Institute for Operations Research and Management Sciences (INFORMS) International Conference Singapore.

Soesilowati, E. S. (2010). Behavior of Muslims in Consuming Halal foods: Case of Bantenese Muslim. Paper presented at the Sharia Economics Research Day, Widya Graha Lipi.

Sood, J., and Nasu, Y. (1995). Religiosity and nationality: An exploratory study of their effect on consumer behavior in Japan and the United States. Journal of Business Research, 34(1), 1-9.

Stark, R., and Glock, C. Y. (1968). American piety: The nature of religious commitment. University of California Press.

Stone, M. (1974). Cross-validatory choice and assessment of statistical predictions. Journal of the Royal Statistical Society, 36(1), 111-147.

Sun, S., Goh, T, Fam, K.S. and Xue, Y. (2012). The influence of religion on Islamic mobile phone banking services adoption. Islamic Journal of Marketing, 3 (1), 81-98.

Swimberghe, K., Sharma, D., and Flurry, L. (2009). An exploratory investigation of the consumer religious commitment and its influence on store loyalty and consumer complaint intentions. Journal of Consumer Marketing, 26(5), 340-347.

Taib, F. M., Ramayah, T., and Razak, D. A. (2008). Factors influencing intention to use diminishing partnership home financing. International Journal of Islamic and Middle Eastern Finance and Management, 1(3), 235- 248.

Tsafe, B. M., and Rahman, R. A. (2013). Effects of spirituality on board performance in Malaysian microfinance firms. Middle-East Journal of Scientific Research, 18(5), 675-688.

Youssef, M. A., Kortam, W., Aish, E. A., and El-Bassiouny, N. (2011). Measuring Islamic-driven buyer behavioral implications: A proposed market-minded religiosity scale. Journal of American Science, 7(8), 728-741. 
Zainuddin, Y., Jahyd, N., and Ramayah, T. (2004). Perception of Islamic banking: does it differ among users and non users. Jurnal Manajemen dan Bisnis, 6(2), 221-232.

Figure 1: Conceptual model

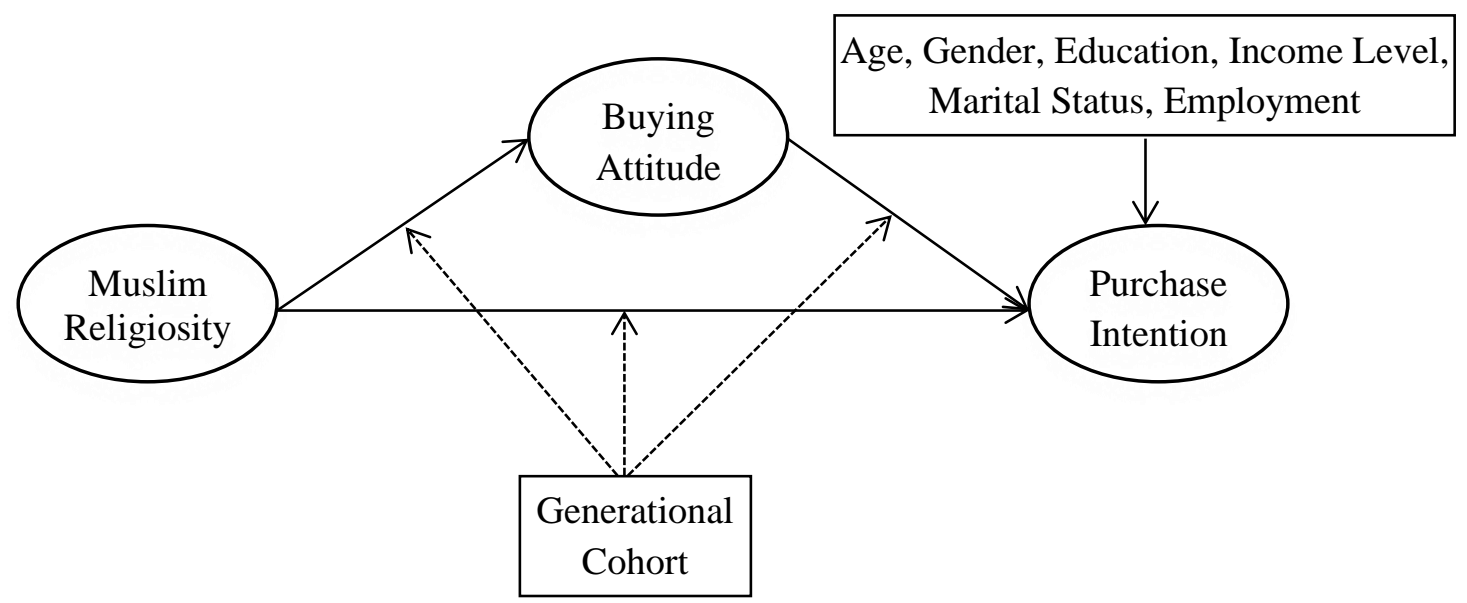

Table 1: Sample characteristics $(\mathrm{n}=1263)$

\begin{tabular}{|l|l|}
\hline Gender & Male $=1085(86 \%)$, Female $=178(14 \%)$, \\
\hline Marital status & Married $=453(36 \%)$, Others $=810(64 \%)$, \\
\hline Employment & Employed $=525(42 \%)$, Others $738(58 \%)$ \\
\hline Education & Secondary = 164 (13\%), Undergraduate =663 $(52 \%)$, Postgraduate $=436(35 \%)$ \\
\hline Location & $\begin{array}{l}\text { Dhaka }=302(24 \%), \text { Sylhet }=217(17 \%), \text { Chittagong }=227(18 \%), \text { Rajshahi }= \\
291(23 \%), \text { Khulna }=226(18 \%)\end{array}$ \\
\hline $\begin{array}{l}\text { Monthly Income } \\
(\text { TK })\end{array}$ & $\begin{array}{l}\leq 15000=628(49.8 \%), 15001-25000=195(15.4 \%), 25001-35000=185 \\
(14.6 \%), 35001-45000=194(15.4 \%), 45000+=61(4.8 \%)\end{array}$ \\
\hline
\end{tabular}


Table 2: The measurement model

\begin{tabular}{|c|c|c|c|}
\hline Latent Variables and Indicators & Loadings & SE & T Value \\
\hline \multicolumn{4}{|l|}{ Muslim Religiosity } \\
\hline $\begin{array}{l}\text { Religious Belief }(R B) P c=.87, A V E=.69 \\
\text { No Other God but Allah and Mohammad is His Prophet } \\
\text { People will be judged on the day of Qayamat } \\
\text { Qur'an is the world of Allah with justified authority }\end{array}$ & $\begin{array}{l}.79 \\
.84 \\
.86\end{array}$ & $\begin{array}{l}.068 \\
.032 \\
.031\end{array}$ & $\begin{array}{l}11.65^{* * *} \\
25.96^{* * *} \\
27.30^{* * *}\end{array}$ \\
\hline $\begin{array}{l}\text { Religious Practice }(R P) P c=.87, A V E=.68 \\
\text { Engage in Dua's } \\
\text { Pray five times a day } \\
\text { Read the Qur'an }\end{array}$ & $\begin{array}{l}.82 \\
.88 \\
.77\end{array}$ & $\begin{array}{l}.018 \\
.010 \\
.020\end{array}$ & $\begin{array}{l}45.73 \text { *** } \\
90.72^{* * *} \\
38.25 * * *\end{array}$ \\
\hline $\begin{array}{l}\text { Religious Knowledge }(R K) P c=.81, A V E=.59 \\
\text { Knowledge of my religion } \\
\text { Try to avoid minor and major sin } \\
\text { Try to follow Islamic junctions in life }\end{array}$ & $\begin{array}{l}.74 \\
.72 \\
.84\end{array}$ & $\begin{array}{l}.031 \\
.031 \\
.017\end{array}$ & $\begin{array}{l}23.72 * * * \\
23.11 * * * \\
48.52 * * *\end{array}$ \\
\hline $\begin{array}{l}\text { Religious Experience }(R E) P c=.84, A V E=.64 \\
\text { Feeling of being punished by Allah for wrong doings } \\
\text { Pleasure is seeing others following Islamic teachings } \\
\text { Answers questions about the meaning of life }\end{array}$ & $\begin{array}{l}.74 \\
.82 \\
.83\end{array}$ & $\begin{array}{l}.033 \\
.020 \\
.017\end{array}$ & $\begin{array}{l}22.60 * * * \\
42.04 * * * \\
48.83 * * *\end{array}$ \\
\hline $\begin{array}{l}\text { Religious Consequences }(R C) P c=.80, A V E=.58 \\
\text { Respect others' rights as per Islamic junctions } \\
\text { Avoid any activity that hurts others } \\
\text { Avoid humiliating others }\end{array}$ & $\begin{array}{l}.82 \\
.67 \\
.78\end{array}$ & $\begin{array}{l}.032 \\
.043 \\
.033\end{array}$ & $\begin{array}{l}25.62^{* * *} \\
15.58^{* * *} \\
23.35^{* * *}\end{array}$ \\
\hline Buying Behaviour & & & \\
\hline $\begin{array}{l}\text { Purchase Intention (PI) } P c=.90, A V E=.69 \\
\text { Eager to learn more about Islamic financial products } \\
\text { Interested to use Islamic financial products } \\
\text { Interested to use Islamic financial products in the future } \\
\text { Definitely recommend Islamic financial products to others }\end{array}$ & $\begin{array}{l}.75 \\
.90 \\
.86 \\
.81\end{array}$ & $\begin{array}{l}.023 \\
.007 \\
.010 \\
.014\end{array}$ & $\begin{array}{l}32.66 * * * \\
134.20 * * * \\
81.48 * * * \\
59.44 * * *\end{array}$ \\
\hline $\begin{array}{l}\text { Buying Attitude }(B A) P c=.90, A V E=.68 \\
\text { Islamic finance operates as per Shariah } \\
\text { Islamic finance follows interest free principle } \\
\text { Islamic finance follows profit and risk sharing principle } \\
\text { Islamic finance is in harmony with my religious values }\end{array}$ & $\begin{array}{l}.86 \\
.91 \\
.78 \\
.75\end{array}$ & $\begin{array}{l}.012 \\
.007 \\
.017 \\
.020\end{array}$ & $\begin{array}{r}73.38 * * * \\
131.38 * * * \\
47.51 * * * \\
37.70 * * *\end{array}$ \\
\hline
\end{tabular}

Control Variables - Age (Years); Education: 1 = Secondary, $2=$ Undergraduate, $3=$ Postgraduate; Gender: Male $=1$, Female $=0$; Marital status: $1=$ Bachelor $/$ Divorced, $0=$ Married; Employment: Employed = 1, else $=0$; Monthly Income $(\mathrm{TK})$ : not appropriate $=1$, Less than $15000=1,15000-25000=2,25001-35000=3,35001-45000=4,45000+=5$

Notes: $P c=$. Composite reliability, $A V E=$ Average variance extracted, $\mathrm{SE}=$ standard error, $* * *=$ significance at .001 
Table 3: Discriminant validity

\begin{tabular}{llllllll}
\hline & \multicolumn{1}{c}{ Constructs } & 1 & 2 & 3 & 4 & 5 & 6 \\
\hline 1 & Buying Attitude & $\mathbf{0 . 8 2 6}$ & & & & & \\
2 & Purchase Intention & 0.569 & $\mathbf{0 . 8 3 1}$ & & & & \\
3 & Religious Belief & 0.164 & 0.230 & $\mathbf{0 . 8 2 8}$ & & & \\
4 & Religious Commitment & 0.202 & 0.290 & 0.251 & $\mathbf{0 . 7 5 9}$ & & \\
5 & Religious Experience & 0.350 & 0.414 & 0.408 & 0.458 & $\mathbf{0 . 7 9 9}$ & \\
6 & Religious knowledge & 0.375 & 0.416 & 0.227 & 0.394 & 0.477 & $\mathbf{0 . 7 6 5}$ \\
\hline
\end{tabular}

Note: Bold figures on the diagonal are the square root values of average variance extracted for each construct

Table 4: Direct and indirect effects of religiosity on purchase intention

\begin{tabular}{|c|c|c|c|c|c|c|}
\hline & $\begin{array}{l}\text { Religiosity } \\
\text { Dimensions }\end{array}$ & $\begin{array}{l}\text { Direct } \\
\text { Effect }\end{array}$ & $\begin{array}{l}\text { Indirect } \\
\text { Effect }\end{array}$ & $\begin{array}{l}\text { Total } \\
\text { Effect }\end{array}$ & $\begin{array}{c}\text { If No } \\
\text { Mediator }\end{array}$ & $\begin{array}{c}\text { Variance } \\
\text { Accounted For }\end{array}$ \\
\hline $\mathrm{RB}$ & Religious Belief & .045 & .001 & .046 & .045 & No mediation^ $^{\wedge}$ \\
\hline $\mathrm{RP}$ & Religious Practice & $.128 * * *$ & $.077 * * *$ & $.204 * * *$ & $.204 * * *$ & .38 Partial Mediation \\
\hline RK & Religious Knowledge & $.110 * *$ & $.096 * * *$ & $.206^{* * * *}$ & $.213 * * *$ & Mediation \\
\hline RE & Religious Experience & $.129 * * *$ & $.079 * * *$ & $.207 * * *$ & $.202 * * *$ & .38 Partial Mediation \\
\hline $\mathrm{RC}$ & Religious Consequences & $.064 *$ & -.013 & .051 & .057 & No Mediation^^ \\
\hline
\end{tabular}

Notes: $* * *=$ significance at $.001, * *=$ significance at $.01, *$ significance at .05 .

$\wedge^{\wedge}$ no mediation as one of the indirect paths is not significant

Figure 2: Mediation analysis results

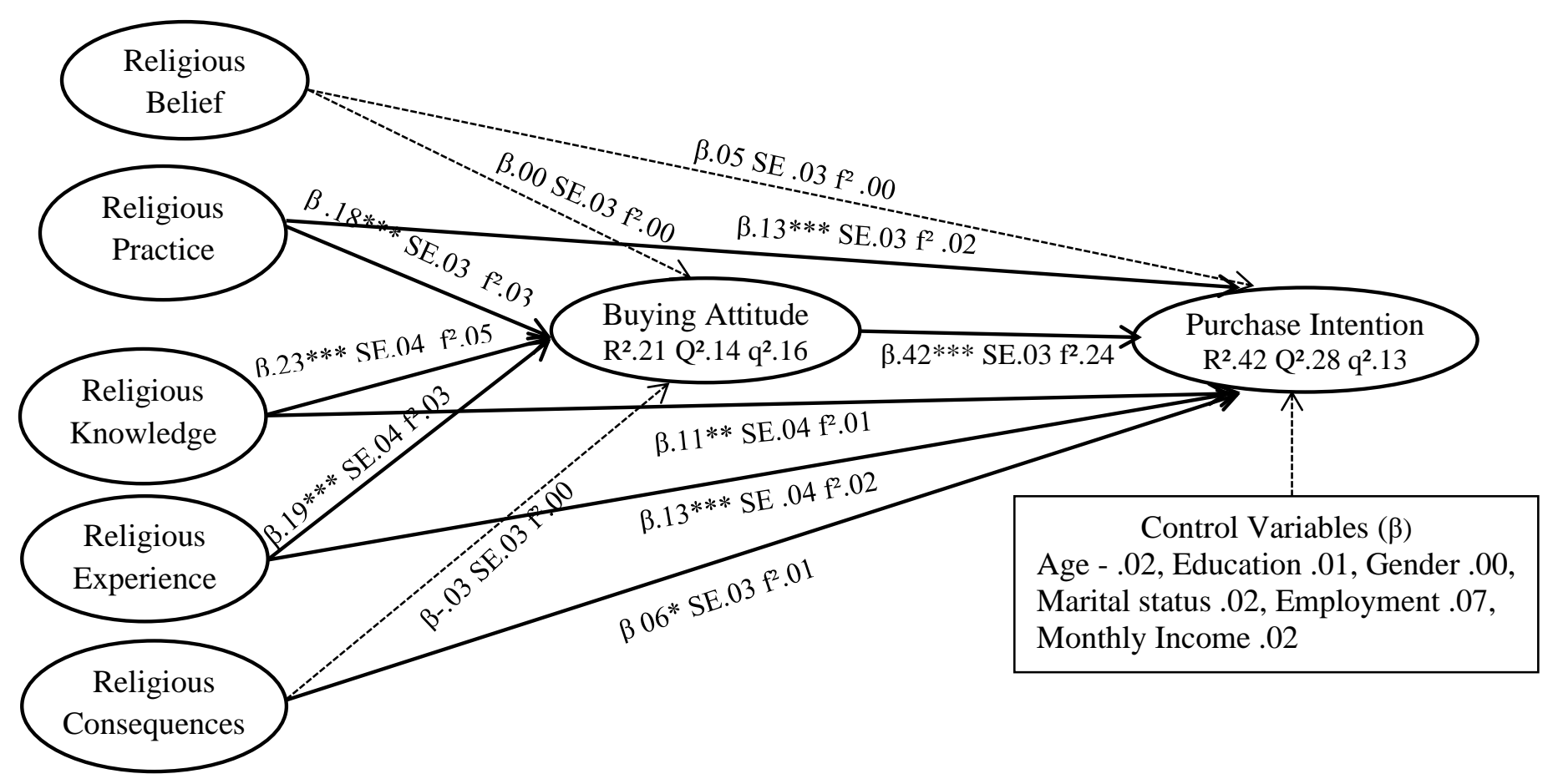

Legends: $\beta=$ standardised path coefficient, $\mathrm{SE}=$ standard error, $\mathrm{R}^{2}=$ coefficient of determination, $\mathrm{f}^{2}=$ effect sizes as the predictive relevance of $\mathrm{R}^{2}, \mathrm{Q}^{2}=$ Stone-Geisser's predictive relevance, $\mathrm{q}^{2}=$ effect sizes as the predictive relevance of $\mathrm{q}^{2}$ $* * *=$ significance at $.001, * *=$ significance at $.01, *$ significance at .05 . 
Table 5: Multi-group analysis: Perceived generational cohorts

\begin{tabular}{|c|c|c|c|c|c|c|c|c|c|c|c|c|}
\hline Path & \multicolumn{4}{|c|}{ GenY } & \multicolumn{4}{|c|}{ GenS } & \multicolumn{4}{|c|}{ GenT } \\
\hline & $\mathrm{DE}$ & IE & $\mathrm{TE}$ & VAF-Med & $\mathrm{DE}$ & $\mathrm{IE}$ & $\mathrm{TE}$ & VAF-Med & $\mathrm{DE}$ & IE & $\mathrm{TE}$ & VAF-Med \\
\hline $\mathrm{RB} \rightarrow \mathrm{PI}$ & .00 & .01 & .01 & No Med & .08 & -.01 & .07 & No Med & .03 & .00 & .03 & No Med \\
\hline $\mathrm{RP} \rightarrow \mathrm{PI}$ & $.16 * * *$ & $.07 * *$ & $.24 * * *$ & .29 Partial & .05 & $.10 * * *$ & $.15^{* *}$ & .67 Partial & $.19 * * *$ & $.07 * *$ & $.26 * * *$ & .27 Partial \\
\hline $\mathrm{RK} \rightarrow \mathrm{PI}$ & .09 & $.07 *$ & $.17 * *$ & .41 Partial & $.15^{*}$ & $.11 * * *$ & $.26 * * *$ & .42 Partial & .05 & $.08 * *$ & $.12 *$ & .67 Partial \\
\hline $\mathrm{RE} \rightarrow \mathrm{PI}$ & .13 & $.17 * * *$ & $.30 * * *$ & .57 Partial & $.16 * *$ & .05 & $.21 * * *$ & No Med & .09 & .01 & .10 & No Med \\
\hline $\mathrm{RC} \rightarrow \mathrm{PI}$ & .05 & .02 & .07 & No Med & .06 & -.04 & .02 & No Med & $.13 * *$ & -.01 & $.12 *$ & No Med \\
\hline $\mathrm{BA} \rightarrow \mathrm{PI}$ & $.48 * * *$ & na & $.48 * * *$ & na & $.38 * * *$ & na & $.38 * * *$ & na & $.45 * * *$ & na & $.45 * * *$ & na \\
\hline $\mathrm{RB} \rightarrow \mathrm{BA}$ & .02 & na & .02 & na & -.02 & na & -.02 & na & .00 & na & .00 & na \\
\hline $\mathrm{RP} \rightarrow \mathrm{BA}$ & $.15^{* *}$ & na & $.15^{* *}$ & na & $.26 * * *$ & na & $.26 * * *$ & na & $.16^{* *}$ & na & $.16^{* *}$ & na \\
\hline $\mathrm{RK} \rightarrow \mathrm{BA}$ & $.15 * *$ & na & $.15 * *$ & na & $.30 * * *$ & na & $.30 * * *$ & na & $.17 * *$ & na & $.17 * *$ & na \\
\hline $\mathrm{RE} \rightarrow \mathrm{BA}$ & $.35 * * *$ & na & $.35 * * *$ & na & .13 & na & .13 & na & .03 & na & .03 & na \\
\hline $\mathrm{RC} \rightarrow \mathrm{BA}$ & .05 & na & .05 & na & -.11 & na & -.11 & na & -.02 & na & -.02 & na \\
\hline Multigrac & $\begin{array}{rr}\text { omparis } \\
19 * & 1) \\
& 4) \\
\end{array}$ & $\begin{array}{l}\text { (Welch } \\
\text {-BA (DH } \\
\text { ucation- }\end{array}$ & $\begin{array}{l}\text { terthwai } \\
\text { GenY a } \\
\text { GenY }\end{array}$ & $\begin{array}{l}\text { ): } \\
\text { ienS } .23 * * \\
*), \text { GenS ( }\end{array}$ & $\begin{array}{l}\text { GenY an } \\
\left.13^{* *}\right), \mathrm{G}\end{array}$ & $\begin{array}{l}\text { IenT } .32 \\
\Gamma(-.09 *)\end{array}$ & $\begin{array}{l}\text {; 2) RP- } \\
\text { enY vs }\end{array}$ & $\begin{array}{l}\text { E) }-\mathrm{GenS} \\
(.30 * * *), \mathrm{C}\end{array}$ & $\begin{array}{l}\text { nd GenT } \\
\text { enY vs G }\end{array}$ & $\begin{array}{l}* ; 3) \mathrm{R} \\
\Gamma\left(.27^{*}\right.\end{array}$ & TE) - & $I$ and \\
\hline $\begin{array}{l}\text { Notes: RB } \\
\text { Purchase I } \\
\text { mediation, }\end{array}$ & $\begin{array}{l}\text { jous B } \\
\text { DE }= \\
\text { appli }\end{array}$ & $\begin{array}{l}\mathrm{RP}=\mathrm{R} \\
\text { ct effect, }\end{array}$ & us Pract & $\begin{array}{l}\mathrm{K}=\text { Relig } \\
\mathrm{t}, \mathrm{TE}=\text { tot }\end{array}$ & $\begin{array}{l}\text { Know } \\
\text { ffect, V }\end{array}$ & $\begin{array}{l}\mathrm{RE}=\mathrm{R} \\
\text { led }=\mathrm{me} \\
\text { icance at }\end{array}$ & $\begin{array}{l}\text { ous Ex } \\
\text { on base }\end{array}$ & $\begin{array}{l}\mathrm{e}, \mathrm{RC}=\mathrm{R} \\
\text { ariance acc }\end{array}$ & $\begin{array}{l}\text { gious Co } \\
\text { inted for }\end{array}$ & Med = & $\begin{array}{l}\text { Buyi } \\
\text { diatio }\end{array}$ & $\begin{array}{l}\text { tude, } \mathrm{PI}= \\
\text { al - partial }\end{array}$ \\
\hline
\end{tabular}


Table 6: Multi-group analysis: Age based generational cohorts

\begin{tabular}{|c|c|c|c|c|c|c|c|c|}
\hline Path & \multicolumn{4}{|c|}{ GenY $(n=624)$} & \multicolumn{4}{|c|}{ GenS and GenT (639) } \\
\hline & $\mathrm{DE}$ & $\mathrm{IE}$ & $\mathrm{TE}$ & VAF-Med & $\mathrm{DE}$ & IE & $\mathrm{TE}$ & VAF-Med \\
\hline $\mathrm{RB} \rightarrow \mathrm{PI}$ & .04 & -.01 & .03 & No Med & .06 & .01 & .07 & No Med \\
\hline $\mathrm{RP} \rightarrow \mathrm{PI}$ & $.15 * * *$ & $.09 * * *$ & $.24 * * *$ & .38 Partial & .07 & $.08 * * *$ & $.15 * *$ & .53 Partial \\
\hline $\mathrm{RK} \rightarrow \mathrm{PI}$ & $.10 *$ & $.08 * * *$ & $.18 * * *$ & .44 Partial & .09 & $.10 * * *$ & $.19 * *$ & .53 Partial \\
\hline $\mathrm{RE} \rightarrow \mathrm{PI}$ & $.14 * *$ & $.13 * * *$ & $.27 * * *$ & .48 Partial & $.13 *$ & .01 & .14 & No Med \\
\hline $\mathrm{RC} \rightarrow \mathrm{PI}$ & .04 & .01 & .05 & No Med & $.14 * * *$ & -.03 & .11 & No Med \\
\hline $\mathrm{BA} \rightarrow \mathrm{PI}$ & $.43 * * *$ & na & $.43 * * *$ & na & $.43 * * *$ & na & $.43 * * *$ & na \\
\hline $\mathrm{RB} \rightarrow \mathrm{BA}$ & -.03 & na & -.03 & na & .02 & na & .02 & na \\
\hline $\mathrm{RP} \rightarrow \mathrm{BA}$ & $.20 * * *$ & na & $.20 * * *$ & na & $.18 * * *$ & na & $.18 * * *$ & na \\
\hline $\mathrm{RK} \rightarrow \mathrm{BA}$ & $.19 * * *$ & na & $.19 * * *$ & na & $.22 * * *$ & na & $.22 * * *$ & na \\
\hline $\mathrm{RE} \rightarrow \mathrm{BA}$ & $.30 * * *$ & na & $.30 * * *$ & na & .03 & na & .03 & na \\
\hline $\mathrm{RC} \rightarrow \mathrm{BA}$ & .01 & na & .01 & na & -.07 & na & -.07 & na \\
\hline \multicolumn{9}{|c|}{$\begin{array}{l}\text { Multigroup Comparisons (Welch Satterthwait test): } \\
\text { 1) RE-BA DE .28***, 2) RE-PI IE.12***, 3) RE-BA TE .28***, 4) Marital Status -PI .12**, 5) Education- PI .19*** }\end{array}$} \\
\hline
\end{tabular}


Appendix One: Perceptual generational cohorts

Please choose one of the following statements that best describes you.

\begin{tabular}{|l|l|}
\hline \multicolumn{1}{|c|}{ Statement } & Tick \\
\hline $\begin{array}{l}\text { Traditionalist Generation: In my opinion, life is really not supposed to be fun and } \\
\text { conformity is good. It is good to be self-disciplined, traditional, money saver, give importance } \\
\text { on safety and security and to make personal sacrifice. }\end{array}$ & \\
\hline $\begin{array}{l}\text { Swing Generation: In my opinion, it is good to be rational, self-reliant, and adaptable. I'm } \\
\text { entrepreneurial, risk averse and value safety and security and strive for comfort in life. }\end{array}$ & \\
\hline $\begin{array}{l}\text { Generation Y: In my opinion, I'm a stimulated person on instant gratification. I have been } \\
\text { depicted as eager and tech savvy, requiring fun and challenges in life and have strong } \\
\text { preference for digital content and social interaction. }\end{array}$ & \\
\hline
\end{tabular}

